\title{
The Influence of Marxist Thoughts on the Ideological and Political Education of College Students
}

\author{
Wu Zhijun \\ (NanChang Institute of Science and Technology, Nanchang,330108)
}

Keywords: Marxism; College students; Ideological politics

\begin{abstract}
Marxist ethnology has always been implementing Marxism. It has gradually emerged in the contemporary era and is a high-level reflection on people. The connotation of Marxist humanities is very rich. Its human nature, human needs, human values, and human development theories are of great value. The ideological and political education of college students is a person's work, pays close attention to the immediate interests of the college students, and develops in an all-round way, guiding college students to form a correct world outlook, outlook on life, and values. The article starts from the theoretical basis of Marx's theory of humanity, and discusses the enlightenment of Marxist human studies on ideological and political education from the perspectives of sociality, history, practice, and comprehensive development.
\end{abstract}

\section{Introduction}

The sinicization of Marxism is a great theoretical achievement produced by combining the basic principles of Marxism with China's reality. It is a concrete embodiment of Marxism in China and has great historical significance and practical value. As the successor of socialist construction in our country, college students are very important in their ideological and political qualities and must be highly valued. From the process of sinicization of Marxism, we get insight and enlightenment, and apply this revelation to college students' ideological and political education. This article is based on the discussion of the main line, and focuses on the enlightenment of Marxism in China on the ideological and political education of Chinese students. The article emphasizes the importance of the sinicization of Marxism in China and the inspiration and guidance of the theoretical achievements on the ideological and political education of college students, and puts forward some specific operational suggestions and methods.

\section{Marxist Philosophy}

Marxist philosophy is a collective term for dialectical materialism and historical materialism. Marx and Engels believe that the unity of the world lies in its materiality, and that matter is the basis for all changes in the world. Movement is the form of existence of matter, the movement of matter is absolute, and the rest is relative. Substance is not a product of the spirit. Spirit is the highest form of material in motion. Social existence determines people's consciousness, and people can recognize and correctly use objective laws. The laws of dialectics are drawn from the history of the natural world and human society, and can essentially be attributed to the following three laws: the law of transformation from quantity to quality and quality to quantity; the law of oppositional mutual penetration; negation of negation law. Dialectics is the science of the most universal laws of all sports. The root cause of the movement is contradiction. Conflicting parties only exist in their interdependence and mutual connection. To understand the laws of movement in the material world, people must go through practice. People should prove the truth of their thinking in practice. The ability of people to understand is limitless, and the knowledge of individual people is limited. This contradiction must be resolved in endless, continuous generations.

Historical materialism holds that the production labor of material life materials is the basis for the existence and development of human society. Laborers and means of production are always factors of production, and the combination of the two constitutes productivity. When people develop productive forces, they also develop a certain degree of interrelationship, that is, production 
relations. The total production relations form a social relationship. The nature of production relations and social relations changes with changes in productivity. People must first eat, drink, live, and wear before they can engage in politics, science, art, and so on. Therefore, the production of material information in each historical era and the resulting social structure are the basis of politics and thought in this era. Since the dissolution of the original commune system, all history has been the history of class struggle. Historical activities are the cause of the masses. People create their own history, but they are created on the basis of real relationships. Individuals have a role in history. Every era needs and can create great people of their own time.

\section{Strengthening and Improving the Guiding Ideology and Basic Principles of Ideological and Political Education for College Students}

\section{The Guiding Ideology for Strengthening and Improving the Ideological and Political Education of College Students}

Adhere to Marxism-Leninism, Mao Zedong Thought, Deng Xiaoping Theory, and the important thinking of the 'Three Represents' as guidance, thoroughly implement the spirit of the 16th Party Congress, and fully implement the party's education. The policy closely combines the reality of building a well-to-do society in an all-round way, focusing on education of ideals and convictions, focusing on patriotic education, building on ideological and moral development, and taking the overall development of college students as the goal, emancipating the mind, seeking truth from facts, advancing with the times, and adhering to the times. People-oriented, close to reality, close to life, close to the students, and strive to improve the ideological and political education of targeted, actual effectiveness and attractiveness, appeal, and cultivate a socialist qualified builders and reliable successors who are all-round development of morality, intelligence, beauty and the United States.

The Basic Principles for Strengthening and Improving College Students' Ideological and Political Education

(1) Adhere to the combination of teaching and educating people. School education should adhere to the principle of educating people and moral education, taking personnel training as the fundamental task, and placing ideological and political education at the forefront.

(2) Combining education with self-education. It is necessary to give full play to the educational and guiding role of school teachers and the caucus organizations, but also to fully mobilize the enthusiasm and initiative of college students, and guide them to self-education, self-management, and self-service.

(3) Adhere to the combination of political theory education and social practice. Both emphasis on classroom education, but also focus on guiding college students to deepen the society, understand the society, serve the community.

(4) Combine solving the ideological issues and solving practical problems. We must both reason and do practical things. We must both rationalize and educate people and increase the actual effect of ideological and political education.

(5) Adhere to the combination of education and management. Integrate ideological and political education into school management, establish a long-term working mechanism, organically combine self-discipline with gastronomy, encouragement, and restraint, and effectively guide college students' thinking and behavior.

(6) Adhere to the combination of inheriting fine traditions and improving innovation. On the basis of inheriting the fine traditions of the party's ideological and political work, it actively explores new ways and new methods for ideological and political education of college students under the new situation, strives to reflect the characteristics of the times, grasps regularity, is full of creativity, and enhances effectiveness.

\section{Study on the Role of Marxist Theory Education in College Students' Ideological and Political Education}

The role of Marxist theoretical education in the ideological and political education of college 
students is one of the hot topics discussed by the ideological and theoretical circles and the education community. The role of Marxist theoretical education in the ideological and political education of college students lies in the fact that it not only provides a scientific theoretical foundation for the establishment of a correct world outlook, outlook on life, and values for college students, but also improves the ability of college students to analyze and solve problems and cultivate their philosophy. Thinking, establishing correct ideals and convictions and political positions, and nurturing their patriotic sentiments all play an important role. For this reason, the researchers conducted extensive research and discussion.

The Role of Cultivating College Students' Philosophical Thinking and Establishing a Scientific World view and Methodology

Marxist materialism and dialectics provide people with a scientific way of thinking about the nature, human society, and people themselves. This principle is the starting point for people to engage in all activities. It requires people to insist on starting from reality, seeking truth from facts, and grasping the nature and the law of change according to the state of affairs. Providing a methodology for understanding the world and transforming the world is an important function of Marxist philosophy. Methodology is the application, development, and realization of a world outlook. The current unhealthy mentality, mentality, and values in college students are aside from social unhealthy thoughts and phenomena. Apart from its influence, the main reason is that it has not mastered the scientific methods of observation, analysis, and understanding of society.

The Role for Undergraduates in Establishing Correct Outlooks on Life, Values and Establishing Sublime Value of Life

The important thinking of the "three represents" is a concentrated expression of contemporary Marxist values and is a socially dominant value in the reconstruction of contemporary university students' values system. This is because the important thinking of the "three represents" reflects the unity of collectives and individuals, material and spiritual life, instrumental values, and purposeful values. Only by mastering a scientific world outlook, outlook on life, and values can we make college students make a correct assessment of the current international and domestic political situation, and then choose the correct position, viewpoints, and methods to take corrective action. Only when it comes to the future of the country and the nation the major political issues of fate and destiny have the correct understanding and attitude, and they can adopt the right attitude and position toward the people and their interests.

\section{The Role for College Students in Establishing Correct Ideals and Beliefs}

Only when we have a complete and accurate understanding of Marxism can we have the desire and pursuit of it, can we firmly believe in their scientific nature, and use Marxism's fighting spirit and critical spirit to counter all kinds of wrong thoughts, and then we can establish communism and Chinese characteristics society. The lofty ideals and beliefs of the doctrine. Marxist theoretical education can enable students to deeply understand the justice, inevitability, and arduousness of communism and socialism, understand the loftiness and beauty of communism and socialism, and guide college students to unify their personal values and social values and make great ideals. Combine with the common ideals to establish the common ideals and beliefs of socialism with Chinese characteristics and devote themselves to the great cause of socialism with Chinese characteristics.

\section{Conclusion}

Marxist theory and the "three outlooks" education are the guiding ideology of ideological and political education in colleges. It sets a scientific world outlook, outlook on life and values for university students, improves their ability to analyze and solve problems, and establishes a correct political position, which plays an important role in establishing correctness of policy,ideals and beliefs, nurturing their patriotic feelings, elevating their moral realm, promoting their overall quality and all-round development of individuals . 


\section{References}

[1] Fiona Tregenna. The specificity of manufacturing in Marx's economic thought[J]. European Journal of the History of Economic Thought, 2013, 20(4):603-624.

[2] Fisk M. Essentialism in the Thought of Karl Marx. by Scott Meikle[J]. Nous, 1985, 22(3):477.

[3] Mclellan D. Karl Marx: His Life and Thought[J]. Slavic Review, 2009, 34(2).

[4] Morrison K. Marx, Durkheim, Weber : formations of modern social thought[J]. Thought A Journal of Philosophy, 2015.

[5] Mandel, Ernest. The Formation of the Economic Thought of Karl Marx[J]. Sources Toronto Canada, 2015.

[6] Mandel, Ernest. The Formation of the Economic Thought of Karl Marx[J]. Sources Toronto Canada, 2015.

[7] Morrison K. Marx, Durkheim, Weber : formations of modern social thought[J]. Thought A Journal of Philosophy, 2015.

[8] Zhang Y F, Yuan L. Scientific Sublation of the Populist Ejido Thought by Marx and Engels[J]. Teaching \& Research, 2013.

[9] Wang X, Marxism S O, University G M. The Logical Approach of Marx's Thought of Community[J]. Journal of Chongqing University of Posts \& Telecommunications, 2017.

[10] Sun H, Wanting L U, Marxim S O, et al. Marx's Industrial Thought and Its Contemporary Enlightenment[J]. Journal of Hubei University of Technology, 2017.

[11] Yang J. A Review of the Research on Marx Thought of Jurisprudence[J]. Theory Research, 2016.

[12]Peng Y, Marxism S O, University H. On the Practicing Path of Marx's Thought of Happiness[J]. Journal of Anqing Normal University, 2017. 